\title{
PENGARUH LATIHAN BOLA PANTUL TERHADAP KETERAMPILAN PASSING BAWAH BOLA VOLI PADA EKSTRAKURIKULER SMP NEGERI 30 MUARO JAMBI
}

\author{
Rasyono \\ e-mail : rasyono@unja.ac.id \\ Fakultas Ilmu Keolahragaan Universitas Jambi
}

\begin{abstract}
Abstrak
Tujuan penelitian ini adalah untuk mengetahui pengaruh latihan bola pantul terhadap keterampilan passing bawah bolavoli peserta ekstrakurikuler SMP Negeri 30 Muaro Jambi. Metode pnelitian ini adalah eksperimen semu menggunakan desain "One Group Pretest-Postest Design". Populasi dalam penelitian ini adalah peserta ekstrakurikuler bolavoli di SMP N 30 Muaro Jambi yang berjumlah 22 siswa. Teknik penarikan sampel yang digunakan adalah total sampling sehingga didapatkan sampel sebanyak 22 siswa. Instrumen yang digunakan adalah tes keterampilan passing bawah. Analisis data menggunakan uji t. Hasil analisis menunjukkan bahwa: latihan bola pantul memberikan pengaruh yang signifikan terhadap keterampilan passing bawah bolavoli peserta ekstrakurikuler di SMP N 30Muaro Jambi, dengan nilai $t_{\text {hitung }} 11,742>$ nilai signifikansi 0,000, dan kenaikan persentase sebesar $48,80 \%$ sehingga Ha diterima. Dengan demikian kesimpulan dari penelitian ini adalah terdapat pengaruh yang signifikan dari latihan bola pantul terhadap keterampilan passing bawah bolavoli peserta ekstrakurikuler SMP N 30 Muaro Jambi.
\end{abstract}

Kata Kunci : Latihan Bola Pantul, Keterampilan Passing Bawah, Ekstrakurikuler

\begin{abstract}
The purpose of this study was to determine the effect of reflex ball training on the volleyball's under-passing skills in the extracurricular members of Muaro Jambi 30 Public Middle School. This research method is a quasi-experimental using the design of "One Group Pretest-Postest Design". The population in this study were volleyball extracurricular participants at Muaro Jambi Middle School 30, totaling 22 students. The sampling technique used was total sampling so that a sample of 22 students was obtained. The instrument used was a test of lower passing skills. Data analysis using t test. The results of the analysis show that: bounce ball training has a significant effect on the volleyball under-passing skills of extracurricular participants in Junior High School 30 Muaro Jambi, with a value of t count 11,742> significance value 0,000, and a percentage increase of $48.80 \%$ so Ha is accepted. Thus the conclusion of this study is that there is a significant effect of reflex ball training on the volleyball's under-passing skills of the extracurricular members of Muaro Jambi 30 Junior High School.
\end{abstract}

\section{Keywords: Ball Reflective Exercise, Lower Passing Skills, Extracurricular}

Dipublikasikan Oleh :

UPT Publikasi dan Pengelolaan Jurnal

Universitas Islam Kalimantan Muhammad Arsyad Al-Banjari Banjarmasin 


\section{PENDAHULUAN}

Bola voli merupakan salah satu cabang olahraga yang sangat popular dan digemari oleh semua kalangan. Oleh sebab itu, bola voli tidak asing lagi bagi masyarakat Indonesia, baik masyarakat perkotaan maupun masyarakat pedesaan karena untuk melakukan olahraga ini tidak membutuhkan biaya yang sangat besar, sarana dan prasarananya pun mudah didapatkan dipasaran. Banyak masyarakat yang menyukai olahraga ini dan banyak pula masyarakat yang ingin mempelajari permainan bola voli secara lebih jauh. Permaianan bola voli adalah permaianan beregu bola besar. Bolavoli dimainkan dua regu tiap regu ada 6 pemain, permainan ini memerlukan koordinasi dan kerja sama tim. Di samping itu, penguasaan teknik-teknik dasar permainan harus matang dengan demikian dapat melakukan gerakangerakan variasi dan kombinasi dari teknik-teknik dasar (Sodikin Chandra (2010: 15).

Permainan bola voli dapat berjalan dengan baik apabila siswa sudah menguasai teknik-teknik dasar permainan bola voli. Adapun teknik dasar permainan bola voli yang dapat dipelajari diantaranya adalah: 1. Servis terdiri dari servis atas dan servis bawah; 2. Passing terdiri dari passing bawah dan passing atas; 3. Smash ; 4. Block. Dari keempat teknik dasar diatas passing merupakan salah satu teknik yang penting dan fundamental dalam permainan bola voli. Bagi para pemula selain servis, smash dan block, passing bawah sangat menentukan jalannya permainan pada bola voli, oleh karena itu untuk pelatihan bola voli disekolah passing bawah adalah teknik terpenting yang harus dipelajari dan dikuasai dengan baik oleh peserta didik.

Passing adalah upaya seorang pemain dengan menggunakan suatu teknik tertentu untuk mengoperkan bola yang dimainkannya kepada teman seregunya untuk dimainkan dilapangan sendiri. Sehingga passing seorang pemain haruslah akurat guna memperoleh strategi penyerangan yang baik pula (Menurut Nuril Ahmadi 2007: 22).

Banyak faktor yang menjadi penyebab kurang baiknya nilai penjasorkes yang diperoleh siswa, salah satunya adalah faktor internal dari diri siswa itu sendiri, dimana siswa merasa jenuh atau bosan dengan materi yang diajarkan oleh guru, karena guru hanya memberikan materi pokok tanpa disertai permainan atau variasi pembelajaran yang menarik yang dapat meningkatkan minat serta motivasi siswa dalam mengikuti pelajaran penjasorkes, sehingga perlu diadakannya materi pembelajaran yang bervariasi dan menarik.

Maka seorang guru dituntut dapat menyajikan pembelajaran menggunakan alat dan metode pembelajaran yang tepat. Alat dan metode pembelajaran memegang peranan penting dalam keberhasilan pembelajaran. Dengan menggunakan alat dan metode pembelajaran yang tepat guru dapat mempermudah penyampaian materi pada siswa. Penggunaan alat diterapkan pada semua mata pelajaran termasuk mata pelajaran Penjasorkes. Pelaksanaan pembelajaran dapat dilakukan dengan latihan-latihan bermain dan bertanding. Pembelajaran penjasorkes memiliki dua materi yang diberikan kepada siswa, dibedakan menjadi dua kelompok yaitu materi pokok dan materi pilihan. Materi pokok merupakan mata pelajaran yang harus diajarkan pada saat jam pelajaran sekolah. Sedangkan materi pilihan merupakan kegiatan olahraga yang dilakukan di luar jam pelajaran sekolah berupa kegiatan ekstrakurikuler olahraga yang lebih menekankan pada pemahaman, penguasaan kemampuan, dan keterampilan diberbagai cabang olahraga.

Salah satu usaha untuk dapat menguasai teknik dasar yang ada dalam permainan bolavoli disekolah maka sekolah mengadakan kegiatan ekstrakurikuler. Adapun kegiatan ekstrakurikuler ini supaya siswa dapat berprestasi sesuai dengan kemauan siswa. Menurut Trueno (2009 : 10), kegiatan ekstrakurikuler adalah kegiatan pendidikan diluar mata pelajaran dan pelayan konseling untuk membantu pengembangan peserta didik sesuai dengan kebutuhan, potensi, bakat dan koordinasi mereka melalui kegiatan yang secara khusus diselenggarakan oleh pendidik dan atau tenaga kependidikan yang berkemampuan dan berkewenangan di sekolah atau madrasah. Tujuan ini mengandung makna bahwa kegiatan ekstrakurikuler berkaitan erat dengan proses belajar mengajar.

Melihat permasalahan yang muncul diatas peneliti tertarik untuk mengadakan penelitian yang berjudul, "Pengaruh latihan bola pantul terhadap keterampilan passing bawah bola voli pada peserta ekstrakurikuler SMP N 30 Muaro Jambi.”

\section{Permainan Bola Voli}

Permainan bola voli merupakan permainan yang kompleks yang tidak mudah dilakukan oleh setiap orang.Sebab didalam permainan bolavoli dibutuhkan koordinasi gerak yang benar-benar bisa Dipublikasikan Oleh : 
diandalkan untuk melakukan semua gerakan yang ada dalam permainan bolavoli

(Menurut Nuril Ahmadi 2007: 20).

\section{Latihan Bola Pantul}

Rasa senang dalam bermain bisa didapatkan dengan bentuk latihan yang menarik, salah satunya dengan bentuk bermain bola pantul. Menurut Durrwatcher (1990: 32), salah satu bentuk latihan bolavoli adalah permainan tenis/bermain bola pantul. Bola yang datang melewati atas net yang di bentangkan mula-mula harus terpantul dulu ke lantai setelah itu dilakukan passing bawah melewati bentangan net kearah teman dilapangan seberang begitu seterusnya.

\section{Passing Bawah}

Passing bawah merupakan teknik memainkan bola dengan sisi lengan bawah bagian dalam baik dengan menggunakan satu ataupun dua lengan secara bersamaan (Menurut Nuril Ahmadi 2007: 22).

Kegunaan passing bawah dalam bola voli antara lain adalah untuk menerima bola servis, menerima bola smash atau serangan dari lawan, untuk mengambil bola setelah terjadi blok atau bola pantul dari net, untuk menyelamatkan bola yang terpantul keluar menjauhi lapangan permainan dan untuk mengambil bola rendah yang datang secara tiba-tiba.

\section{METODE}

Penelitian ini merupakan penelitian percobaan (eksperimen research) karena peneliti ingin mengetahui secara nyata terhadap variabel yang diberi perlakuan khusus. Adapun rancangan penelitian ini menggunakan rancangan One Group, Protest-Postest Design yaitu suatu kelompok yang diberikan perlakukan tetapi sebelum perlakuan diberikan terlebih dahulu tes awal (pretest), kemudian diakhiri dengan tes akhir (postest), seperti bagan berikut:

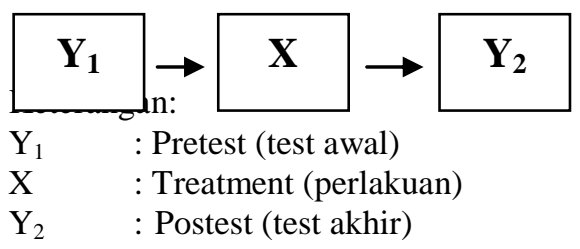

\section{Populasi}

Populasi adalah keseluruhan subyek penelitian. Populasi dalam penelitian ini adalah seluruh peserta yang mengikuti ekstrakurikuler bola voli di SMPN 30 Muaro Jambi yang berjumlah 22 siswa. Sampel

Sampel adalah bagian dari populasi yang mewakili populasi yang akan diambil. Teknik pengambillan sampel dalam penelitian ini adalah total sampling, total sampling adalah teknik pengambilan sampel dimana jumlah sampel sama dengan jumlah populasi (Sugiyono, 2007). Sampel dalam penelitian ini adalah semua peserta ekstrakurikuler SMP N 30 Muaro Jambi yang berjumlah 22 siswa.

\section{Instrumen penelitian}

Tes yang digunakan dalam penelitian ini adalah tes keterampilan passing bawah bola voli. Alat yang digunakan dalam pelaksanaan penelitian keterampilan passing bawah bola voli adalah sebagai berikut :

1. Bola voli; 2. Lapangan bola voli; 3. Peluit; 4. Blangko penilaian; 5. Alat tulis.

\section{Teknik pengumpulan data}

Teknik pengumpulan data dalam penelitian ini adalah dengan cara memberikan perlakuan dengan bermain bola pantul yang gunanya adalah untuk meningkatkan teknik dasar bola voli khususnya passing bawah. Dalam penelitian ini sampel akan melakukan tes passing bawah bola voli pada pretest dan postest guna untuk melihat keterampilan siswa.

Sesudah melakukan tes awal sampel akan diberikan perlakuan dengan latihan bola pantul guna untuk melihat peningkatan pada teknik dasar passing bawah siswa.

Dipublikasikan Oleh :

UPT Publikasi dan Pengelolaan Jurnal

Universitas Islam Kalimantan Muhammad Arsyad Al-Banjari Banjarmasin 


\section{HASIL DAN PEMBAHASAN}

Berdasarkan analisis data hasil penelitian diperoleh peningkatan yang signifikan terhadap kelompok yang diteliti. Pemberian perlakuan selama 14 kali pertemuan dengan frekuensi 2 kali seminggu memberikan pengaruh terhadap peningkatan passing bawah bolavoli peserta ekstrakurikuler di SMP N 30 Muaro Jambi.

Hasil analisis menunjukkan bahwa terdapat peningkatan passing bawah peserta ekstrakurikuler bolavoli di SMP N 30 Muaro Jambi sebelum dan sesudah latihan bola pantul. Hal ini ditunjukkan dengan nilai $\mathrm{t}$ hitung $11,742>$ nilai signifikansi 0.000 , maka hasil ini menunjukkan terdapat perbedaan yang signifikan. Dengan demikian hipotesis alternatif (Ha) yang berbunyi "terdapat pengaruh latihan bola pantul terhadap peningkatan keterampilan passing bawah bolavoli peserta ekstrakurikuler di SMP N 30 Muaro Jambi", diterima. Artinya latihan bola pantul memberikan pengaruh yang signifikan terhadap keterampilan passing bawah peserta ekstrakurikuler di SMP N 30 Muaro Jammbi. Dari data pretest memiliki rerata 41,27, selanjutnya pada saat postest rerata mencapai 61,41. Besarnya peningkatan keterampilan passing bawah bolavoli tersebut dapat dilihat dari perbedaan nilai rata-rata yaitu sebesar 20,14, dengan kenaikan persentase sebesar $48,80 \%$.

Latihan bola pantul merupakan bentuk latihan yang mudah dilakukan karena siswa akan memiliki banyak waktu untuk melakukan gerakan mengambil bola yang memantul ke lantai. Bola yang memantul akan memberikan banyak waktu kepada siswa untuk melakukan gerakan atau teknik selanjutnya. Kemudian, dengan latihan bola pantul ini siswa akan dapat merasa lebih senang dan mudah berhasil dalam menguasai teknik dalam bermain bolavoli. Dimana keberhasilan itu dapat mendorong siswa untuk mencapai keberhasilan berikutnya. Menurut Durrwachter (1990:32) bahwa permainan bola pantul dimaksudkan untuk melatih rentang tungkai dan tubuh pada saat melakukan passing. Dengan adanya pembenaran teknik passing, siswa akan lebih mudah dalam melakukan passing bawah. Selain itu, permainan bola pantul ini akan mengubah suasana tegang menjadi santai sehingga akan membuat siswa nyaman dalam melakukan latihan passing bawah. Keadaan ini akan sangat membantu siswa dalam mempraktekkan keterampilan passing bawah dengan baik dan lebih termotivasi untuk lebih giat dalam berlatih melalui permainan yang diberikan.

Penguasaan teknik dasar passing bawah dalam permainan bolavoli adalah penting karena keberhasilan suatu regu dalam pertandingan bolavoli banyak ditentukan oleh passing. Teknik passing bawah selalu dipergunakan dalam permainan untuk receive servis, bertahan dari serangan lawan ataupun untuk menyusun serangan. Teknik passing bawah ini harus dipelajari sejak dini dan merupakan dasar bagi atlet pemula untuk mengembangkan teknik pasing bawah yang lainnya. Dalam bermain bolavoli atlet dituntut untuk selalu aktif bergerak di dalam lapangan. Oleh karena pada saat bermain bolavoli arah bola yang akan dipassing datangnya belum tentu sesuai dengan apa yang diharapkan, sehingga menuntut untuk bergerak mendekat bola agar dapat dipassing dengan baik. Selain dapat di passing dengan baik, arah bola juga harus tepat mengarah kepada pengumpan agar pengumpan lebih mudah untuk menyusun serangan atau melakukan umpan yang bervariatif, sehingga serangan tidak mudah dibaca oleh lawan.

\section{PENUTUP}

\section{Kesimpulan}

Berdasarkan hasil analisis data, deskripsi, pengujian hasil penelitian, dan pembahasan, dapat diambil kesimpulan, yaitu: latihan bermain bola pantul memberikan pengaruh yang signifikan terhadap keterampilan passing bawah peserta ekstrakurikuler bolavoli putra di SMP N 30 Muaro Jambi, dengan nilai $\mathrm{t}$ hitung $11,742>$ nilai signifikansi 0,000 , dan kenaikan persentase sebesar 48,80\% sehingga Ha diterima.

\section{Saran}

Berdasarkan kesimpulan penelitian di atas, ada beberapa saran yang dapat disampaikan yaitu:

1. Bagi peneliti selanjutnya agar menambah variabel pembanding.

2. Bagi peneliti selanjutnya agar sampel harus lebih dikontrol.

3. Dalam skripsi ini masih banyak kekurangan, untuk itu bagi peneliti selanjutnya hendaknya mengembangkan dan menyempurnakan program latihan pada penelitian ini. 


\section{REFERENSI}

Amung Ma'mun dan Yudha. 2000. Perkembangan Gerak Dan Belajar Gerak. Jakarta : Depdikbud.

Barbara L. Viera \& Bonnie J. Freguson. 2004. Bolavoli Tingkat Pemula. Jakarta: PT.Rajagrafindo Persada.

Depdikbud. (1994). Pendidikan Jasmani. Jakarta: PT. Rajasa Rasdakarya.

Durr Wachter G. 1990. Bola Volley : Belajar Dan Berlatih Sambil Bermain. Jakarta : Gramedia.

Mochamad Moeslim. 2009. Dalam Resha Rafsanjani Prihawan. Model Bermain Bolavoli Dalam Permainan Bolavoli. Disampaikan dalam http://blogmrcaft.com/2011/09/peningkatankemampuan-teknik-dasar.html. (diakses 30 Agustus 2017).

Muhajir. 2007. Pendidikan Jasmani Dan Kesehatan. Bandung : Erlangga.

M. Yunus. 1992. Olahraga Pilihan Bola Voli. Depdikbud.

Nuril Ahmadi. 2007. Pendidikan Olahraga Bola Voli. Surakarta : Era Pustaka Utama.

P. Hari Wibowo. 2009. Upaya Meningkatkan Prestasi Belajar Passing Atas Bola Voli Melalui Pendekatan Bermain Bola Pantul Pada Siswa Kelas VII E SMP N 5 Purwokerto Tahun Pelajaran 2008/2009. Skripsi. Yogyakarta : FIK UNY.

Sugiyono. 2007. Statistika Untuk Penelitian. Bandung: CV. Alfabeta.

Suharno. 1979. Dasar-dasar Permainan Bolavoli. Yogyakarta. IKIP Yogyakarta.

Sukintaka. 1992. Teori Pendidikan Jasmani. Solo: ESA Grafika.

Trueno. 2009. Pengertian Kegiatan Ekstrakurikuler. Disampaikan dalam http://teachonly13.wordpress.com/2009/07/04/pengertian-kegiatan-ekstra-kurikuler/. (diakses 22 desember 2017)

Yusuf Adisasmita \& Aip Syarifuddin (1996). Ilmu Kepelatihan Dasar. Jakarta: Depdikbud. Dirjendikti. Proyek Pendidikan Tingkat Akademik

Yohanes Aji Nugroho. 2015. Pengaruh Permainan Bola Pantul Terhadap Kemampuan Passing Bawah Pada Peserta Eksrta Kulikuler Bola Voli Di SMPN Institut Indonesia Yogyakarta. Skripsi. Yogyakarta. FIK UNY.

Dipublikasikan Oleh :

UPT Publikasi dan Pengelolaan Jurnal

Universitas Islam Kalimantan Muhammad Arsyad Al-Banjari Banjarmasin 